\title{
Penerapan Pendekatan BCCT di KB-TK Realfunrainbow Preschool Salatiga
}

\author{
Dionysia Nova Ardiana ${ }^{1}$, Ajeng Ayu Widiastuti ${ }^{2 凶}$ \\ Pendidikan Guru Pendidikan Anak Usia Dini, Universitas Kristen Satya Wacana \\ DOI: $10.31004 /$ obsesi.v5i1.707
}

\begin{abstract}
Abstrak
Pelaksanaan pendekatan BCCT di KB/TK Realfunrainbow Preschool Salatiga mengalami berbagai kendala sehingga dilakukan kebijakan baru untuk mengatasinya. Penelitian ini bertujuan untuk mengetahui penerapan, faktor pendukung dan penghambat, alasan perubahan kebijakan serta mengetahui upaya-upaya dalam mengatasi problematika penerapan pendekatan BCCT. Penelitian ini merupakan penelitian kualitatif. Data dikumpulkan melalui observasi, wawancara, dan dokumentasi. Data dianalisa dengan metode deskriptif. Hasil menunjukkan bahwa kebingungan pada anak, fokus anak dalam menyelesaikan tugas atau proyek pada sentra-sentra, kesulitan guru membuat rancangan pembelajaran, dan kesulitan guru melakukan evaluasi menjadi alasan perubahan kebijakan. Hubungan antara pendidik dengan orang tua sangat baik, fasilitas atau sarana prasarana yang ada sudah cukup memadai, kurikulum sudah terstruktur untuk membantu pendidik dalam membuat rencana pembelajaran, dan minimnya kebosanan anak menjadi faktor-faktor pendukung perubahan kebijakan ini. Meskipun masalah pembagian waktu pendidik membuat RKH, kurangnya pengembangan ragam main dan menciptakan APE yang disesuaikan dengan tema, pola perubahan serta kemampuan SDM sebagai faktor-faktor penghambat.
\end{abstract}

Kata Kunci: pendekatan bcct; bermain; anak usia dini.

\section{Abstract}

The implementation of the BCCT approach in KB/TK Realfunrainbow Preschool Salatiga experienced various obstacles so that a new policy was implemented to overcome them. This study aims to determine the application, supporting and inhibiting factors, reasons for policy changes and knowing the efforts to overcome the problems. This is a qualitative research. Data were collected through observation, interviews, and documentation. Data were analyzed using descriptive methods. The results show that confusion in children, children's focus in completing assignments or projects in centers, difficulties for teachers in making lesson plans evaluating are reasons for policy changes. The relationship between educators and parents is very good, the existing facilities or infrastructure are adequate, the curriculum is structured to help educators in making lesson plans, and the lack of children's boredom are supporting factors. Despite the problem of allocating time for educators to make lesson plans, the lack of developing a variety of games and creating education toys, patterns of change and the ability of human resources are inhibiting factors.

Keywords: bcct approach, play; early childhood.

Copyright (c) 2020 Dionysia Nova Ardiana, Ajeng Ayu Widiastuti

$\triangle$ Corresponding author:

Email Address : ajeng.ayu@uksw.edu (Jln. Diponegoro No. 52-60, Salatiga, Jawa Tengah)

Received 5 August 2020, Accepted 20 August 2020, Published 24 August 2020 


\section{PENDAHULUAN}

Bermain adalah suatu aktifitas yang merupakan cara bagi anak untuk mengeksplorasi lingkungan. Anak mampu mengembangkan aspek-aspek perkembangannya. Bermain memiliki pengaruh yang sangat besar bagi perkembangan seorang anak. Anak- anak tidak perduli apakah kondisi fisik dan psikis bagus atau tidak, semuanya dilakukan dengan senang, karena pada hakikatnya bermain adalah kebutuhan bagi anak (Fauziddin \& Mufarizuddin, 2018). Kegiatan bermain ini seyogyanya terwadahi di dalam pendidikan anak usia dini. Oleh karena itu, ketika lembaga pendidikan ingin membuat rancangan pembelajaran sebaiknya memperhatikan aktifitas bermain yang hendak dilakukan bersama-sama antara guru dengan anak-anak (Hijriati, 2017; Musfiroh, 2012). Banyak pendekatan pembelajaran yang bisa dilakukan di lembaga-lembaga PAUD untuk mengaplikasikan kegiatan bermain salah satunya pendekatan Beyond Center And Circle Time (BCCT) (Rindaningsih, 2012).

Pendekatan BCCT merupakan pendekatan yang berpusat pada anak yang dalam proses pembelajarannya berpusat di sentra main dan saat anak dalam lingkaran (Dewi et al., 2017; Yuyun Istiana, 2014). Pendekatan BCCT dicetus oleh seorang ahli PAUD berkebangsaan Italia, yaitu Maria Montessori (1870-1952) yang memfokuskan kegiatan anakanak di sentra untuk mengoptimalkan seluruh kecerdasan anak. Pendekatan ini dikembangkan melalui hasil kajian pengembangan dari pendekatan Montessori, High Scope, Head Star, Reggio Emilia yang dikembangkan oleh The Creative Center for Childhood Research and Training (CCCRT) di Florida, Amerika Serikat dan di Indonesia telah diterapkan secara baik antara lain di Sekolah Al-Fallah Jakarta Timur dan Kelompok Bermain Istiqlal Jakarta. Pendekatan ini telah diterapkan di Creative Pre School Florida USA selama 35 tahun, baik untuk anak normal maupun anak dengan kebutuhan khusus (Dewi et al., 2017). Strategi BCCT adalah suatu strategi dalam penyelenggaraan pendidikan anak usia dini merupakan perpaduan antara teori dan pengalaman praktik (Hasanah, 2019), dengan menggunakan pembelajaran BCCT yang menyenangkan ini anak lebih termotivasi lagi untuk terus mencoba hal-hal yang baru (Setiyarini et al., 2015).

BCCT merupakan pendekatan penyelenggaraan PAUD yang berpusat pada anak yang dalam proses pembelajarannya berpusat di sentra main dan saat anak dalam lingkaran (Yuyun Istiana 2014; Hijriati, 2017). Pendekatan BCCT atau yang biasa disebut dengan SELI (Sentra dan Lingkaran) atau sekarang lebih dikenal dengan pembelajaran sentra adalah pendekatan pembelajaran yang digunakan untuk melatih perkembangan anak dengan menggunakan metode bermain yang berfokus pada anak.Implementasi pembelajaran dengan pendekatan BCCT sudah banyak dilakukan sebelumnya (Hijriati, 2017; Rindaningsih, 2012). Menurut Piaget (1972) dalam pelaksanaannya anak dituntut aktif dan kreatif dalam kegiatan di sentra-sentra, artinya anak aktif melakukan percobaan dan penelitian sendiri sehingga anak belajar dari pengalaman yang diperolehnya.

Iswantiningtyas \& Wulansari (2019) menyatakan BCCT ini diyakini mampu merangsang seluruh aspek kecerdsasan anak melalui bermain yang terarah, setting pembelajaran yang mampu merangsang anak selalu aktif, kreatif, dan terus berpikir dengan menggali pengalamannya sendiri. Anak didorong untuk bermain di sentra-sentra kegiatan, sedangkan pendidik berfungsi sebagai perancang, pendukung, dan penilai kegiatan anak. Sehingga BCCT efektif digunakan pada pembelajaran pada anak usia dini.

Dalam pendekatan BCCT setidaknya ada empat pijakan yaitu pijakan lingkungan bermain, sebelum bermain, selama bermain, dan setelah bermain. Tujuan BCCTmenurut (Yuyun Istiana, 2014) yaitu: merangsang seluruh aspek kecerdasan anak serta mendesain suasana belajar yang menstimulasi anak lebih aktif, mengasah kreativitas dan merangsang pikirannya untuk menggali lebih banyak pengalaman-pengalaman baru yang dialaminya. (Rindaningsih, 2012). Menurut Latif dkk (2013) dalam (Zaman et al., 2010) menyatakan ada 6 sentra yang dikembangkan oleh Pamela Phelps, yaitu : sentra persiapan, sentra balok, sentra main peran, sentra bahan alam, sentra seni, dan sentra imtaq. Ada tiga peran guru didalam 
pembelajaran dengan pendekatan BCCT ini, diantaranya guru PAUD sebagai fasilitator, guru PAUD sebagai motivator, guru PAUD sebagai evaluator. Proses Pembelajaran dengan menggunakan pendekatan BCCT, yaitu: penataan lingkungan main, baris-berbaris, penyambutan anak, bermain pembukaan, masa transisi (10 menit), kegiatan inti di masingmasing kelompok, makan bekal bersama, kegiatan penutup, evaluasi.

Di KB-TK Realfunrainbow Salatiga ini hanya terdapat 5 kelas sentra yaitu sentra persiapan, sentra memasak dan bahan alam, sentra teknologi, sentra seni, dan sentra bermain peran. Akan tetapi, untuk sentra imtaq tidak ada kelas tersendiri seperti ke lima sentra yang ada. Namun penerapan pembelajaran yang umumnya ada di sentra imtaq diganti dengan penerapan setiap pagi anak melakukan pembiasaan dengan pembelajaran agama. Dalam pembelajaran agama tersebut anak di bagi di tiap-tiap kelas yaitu kelas KB Islam, kelas TK Islam, kelas KB Kristen-Katholik, kelas TK Kristen-Katholik.

Setiap harinya, siswa berpindah kelas (moving class) disesuaikan dengan tema sentra pada hari tersebut. Di KB-TK Realfunrainbow ini terdapat 4 kelas yang terdiri dari Kelas Eggs (KB A), Kelas Catterpilars A dan B (KB B), Kelas Coocons (TK A), dan Kelas Butterflies (TK B). Akan tetapi di tahun pembelajaran 2020 ini KB-TK Realfunrainbow mengambil kebijakan dalam menerapkan pendekatan BCCT dengan cara anak-anak berkegiatan di 1 sentra dalam satu minggu, sehingga perpindahan kelasnya tidak satu hari satu kali atausatu sentra tetapi satu minggu hanya satu sentra saja

Berdasarkan pemaparan di atas, peneliti tertarik untuk meneliti lebih jauh mengenai bagaimana penerapan pendekatan BCCT dilakukan di KB-TK Realfunrainbow Salatiga. Selain itu, peneliti bermaksud mengkaji faktor pendukung dan penghambat, upaya-upaya dalam mengatasi problematika penerapannya serta alasan perubahan kebijakan yang dilakukan berkaitan dengan penerapan pendekatan BCCT.

\section{METODOLOGI}

Penelitian ini menggunakan pendekatan kualitatif (Moleong, 2017). Penelitian ini dilaksanakan di KB-TK Realfunrainbow Salatiga yang berada di Jl. Penggalang No. 2-4, Salatiga, Kec Sidorejo, Kota Salatiga, Jawa Tengah. Objek dalam penelitian ini yaitu penerapan pendekatan BCCT, faktor pendukung dan hambatan dalam penerapan pendekatan $\mathrm{BCCT}$, alasan dengan adanya perubahan kebijakan, dan upaya untuk mengatasi problematika dalam menerapkan pendekatan BCCT di KB-TK Realfunrainbow Salatiga.

Menurut Basrowi dan Suwandi (2008) dalam (Rahmat, 2009) menyatakan bahwa penelitian kualitatif adalah salah satu prosedur penelitian yang menghasilkan data deskriptif berupa ucapan atau tulisan dan perilaku orang-orang yang diamati.Penelitian kualitatif adalah penelitian yang pemecahan masalahnya dilakukan dengan menggunakan data empiris.

Subyek dalam penelitian ini meliputi 1 kepala sekolah, 10 pendidik KB-TK Realfunrainbow Salatiga. Data dikumpulkan melalui observasi, wawancara, dan dokumentasi. Kemudian dilakukan analisa data kualitatif dimana data yang diperoleh dianalisa dengan metode deskriptif non statistik dengan cara berfikir induktif, yaitu penulis dalam meneliti dimulai dari fakta-fakta yang bersifat empiris.

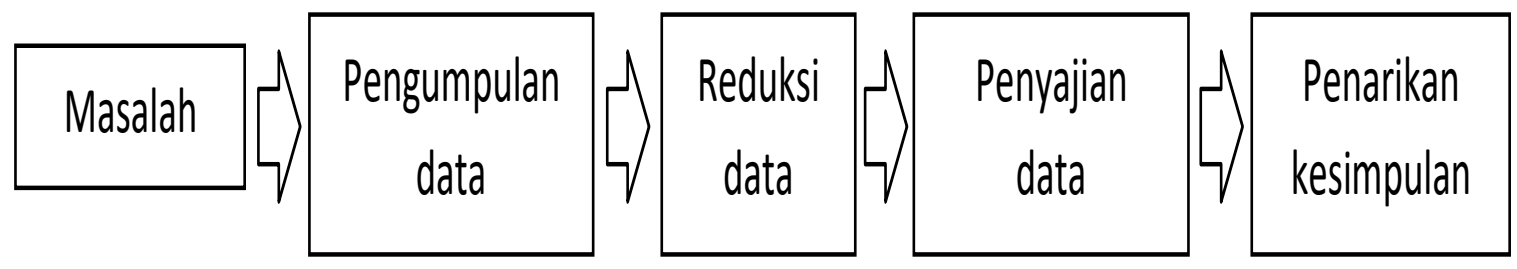

Gambar 1. Desain Penelitian (Sugiyono, 2016) 


\section{HASIL DAN PEMBAHASAN \\ Pendekatan BCCT}

Perencanaan RPPH dibuat oleh guru dengan mengacu pada program semester dan mingguan yang disesuaikan dengan tema dan sub temanya serta pijakan lingkungan main dilakukan sebagai persiapan pembelajaran. $\mathrm{RPPH}$ berisi data keterangan tentang hari/tanggal, tema/subtema,alokasi waktu, nama kelompok, sentra, kegiatan main, indikator, dan pijakan-pijakan dalam bermain. RPPH berfungsi sebagai dasar pelaksanaan pembelajaran dari kurikulum yang telah didesain (Alya, 2019; Fitri, 2017).

Dalam pelaksanaanya, pembelajaran dilakukan melalui beberapa pijakan saat sebelum main, selama main, setelah main, dan kegiatan main di sentra. Pijakan sebelum main berisi kegiatan pembuka di dalam lingkaran seperti bernyayi, bergerak, kuis kemudian dilanjutkan dengan kegiatan keagamaan (Holis, 2016; Wiwik Pratiwi, 2017).

Setelah itu baru menuju sentra, guru membuka kegiatan dengan salam, berdoa, tanya kabar, menjelaskan tema, menggalipengalaman anak, menjelaskan kegiatan, membuat aturan main dan mendemonstrasikan kegiatan yang akan dilakukan. Pijakan selama main berisi kegiatan main anak, guru berkeliling dan mengawasi setiap kegiatan yang dilakukan anak kemudian diobservasi dan didokumentasikan sebagai bahan pelaporan pada orangtua. Pijakan menyiapkan anak untuk belajar dan menjelaskan tentang cara dan aturan bermain (Rozalena \& Kristiawan, 2017).

Guru berkeliling sambil memberikan pujian (Chairilsyah, 2012) atau bantuan bagi anak yang mengalami kesulitan saat bermain kemudian anak mengumpulkan hasil karyanya. Selanjutnya pijakan kegiatan berupa membereskan bahan atau alat main yang telah digunakan kemudian mencuci tangan, berdoa, dan makan bersama. Ketika makan, anak-anak dihimbau agar makan makanan yang sehat dan bergizi serta berbagi dengan anak lain. Kegiatan dilanjutkan dengan berdoa, membereskan alat makan, tanya jawab seputar kegiatan yang telah dilakukan kemudian memakai sepatu dan tas, berbaris, berdoa, dan pulang. Kegiatan main di sentra berisi kegiatan yang dilakukan di sentra menggunakan ragam jenis main yang telah dirumuskan sebelumnya. Seperti yang dikemukakan, tiap sentra dilengkapi dengan per mainan edukatif untuk merangsang anak bermain meski sebenarnya mereka sedang belajar. Alat permainan yang ditata harus mempertimbangkan intensitas dan densitasnya pengalaman main (Rindaningsih, 2012).

Evaluasi pembelajaran dilakukan dalam rangka penilaian terhadap setiap kegiatan yang dilakukan anak baik proses maupun hasil karya mereka. Semua proses penilaian merupakan bagian yang tidak terpisahkan dari proses pembelajaran dan bersifat menyeluruh (holistik) yang mencakup semua aspek perkembangan (Zahro, 2015). Penilaian ini dilakukan dengan cara mengobservasi kegiatan yang sedang dilakukan oleh anak, bertanya untuk menggali gagasan anak, lalu mendokumentasikan setiap kegiatan anak baik proses maupun hasil yang kemudian diberikan penilaian secara keseluruhan.Penilaian ini kemudian dilaporkan kepada orangtua. Pelaporan hasil kegiatan anak dilakukan setiap hari setelah pembelajaran selesai sedangkan pelaporan hasilperkembangan anak dilakukan pada saat akhir semester.Hal ini menegaskan bahwa evaluasi pada pendidikan anak usia dini merupakan suatu proses kegiatan yang bertujuan untuk mengumpulkan data atau buktibukti tentang perkembangan dan hasil belajar yang berkaitan dengan perkembangan anak usia dini (Amini, 2014; Ma'rifah A \& Muthmainnah, 2015).

\section{Pemahaman tentang pendekatan BCCT}

Dari hasil observasi dan wawancara, sebagian besarguru memahami pendekatan BCCT yang dilakukan di KB/TK Realfunrainbow Salatiga secara umum. Dari pemahaman subyek penelitian mengatakan bahwa pendekatan BCCT adalah suatu proses pembelajaran dimana pendekatan yang berfokus pada anak, melalui kelas sentra dengan berbagai pijakan. Pemahaman mereka sangat bervariasi terhadap pendekatan BCCT yang dilaksanakan di sentra-sentra. 
"Pendekatan yang berfokus pada anak, melalui kelas sentra dengan beberapa pijakan."

(D)

"Pendekatan yang berfokus pada anak yang dilaksanakan dengan kelas sentra dan melalui pijakan-pijakan." (P)

Guru percaya bahwa pendekatan BCCT dapat memberikan kesempatan seluas-luasnya untuk anak belajar sesuai dengan ketertarikan, minat dan kemampuan mereka tanpa harus bergantung pada guru sepenuhnya.

"Pendekatan yang berpusat sesuai dengan kemampuan anak." (R)

"Dimana kita memberikan kesempatan untuk anak belajar sesuai dengan keinginan mereka tanpa berpusat dengan guru. Anak bebas memilih permainan yang sudah kita sediakan, anak-anak juga bebas mau bermain secara individu atau dengan kelompok." (W)

"Sejauh yang saya tahu karena ada 3 macam perkembangan yang diatur di BCCT. Menurut saya, pendekatan sentra akan mengacu pada ke itu dan kita mencari tahu sebenarnya apa sih kecerdasan yang dari 9 kecerdasan tersebut." (Y1)

Beberapa guru lain mengakui belum memahami BCCT secara spesifik dikarenakan pengalaman dan latar belakang mereka. Namun, secara umum mereka memahami bahwa pendekatan BCCT memungkinkan anak untuk bermain sambil belajar dalam lingkaran dan setiap sentra memiliki tujuannya secara spesifik terhadap aspek perkembangan anak.

"Untuk pemahaman tentang pendekatan BCCT. Saya tidak paham karena saya memang dari awal kuliah juga tidak ambil pendidikan AUD. Jadi, mungkin bisa tanya lebih jelasnya ke guru di sentra bermain peran yaitu guru Y1." (Y2)

"Aku paham tentang pendekatan sentra hanya secara umum saja tidak secara spesifik. Sejauh yang aku tahu itu pendekatan sentra itu pusatnya kepada anak. Jadi, proses pembelajarannya itu pada kegiatan bermain sambil belajar anak-anak dan di dalam circle time." (A)

"Kalau untuk pendekatan sentra itu sendiri saja tidak begitu tahu. Yang saya tahu selama ini hanya untuk pembelajaran di tiap sentra. Karena saya dulunya menjadi asisten di kelas sentra teknologi, dan sekarang saya menjadi asisten di kelas sentra masterchef. Yang saya tahu bahwa kalau di kelas sentra teknologi itu untuk melatih linguistik anak, kalau di kelas sentra masterchef lebih ke motorik anak." (L)

\section{Alasan adanya perubahan kebijakan di dalam proses pembelajaran pendekatan BCCT}

KB/TK Realfunrainbow Salatiga sejak awal berdirinya sekolah sudah menerapkan pendekatan BCCT di dalam proses pembelajaran yang dilakukan 1 minggu dengan sentra yang berbeda-beda setiap harinya. Akan tetapi perubahan kebijakan baru dalam penerapan pendekatan BCCT kemudian dilakukan dimana proses pembelajaran dilakukan dengan hanya menerapkan satu sentra saja setiap minggunya. Berdasarkan informasi yang didapatkan, perubahan kebijakan ini antara lain dijabarkan di bawah ini.

Kebingungan pada anak. Menurut subyek, terjadi kebingungan pada anak dalam penerapan pendekatan BCCT dengan sentra yang berbeda-beda setiap harinya. Subyek mengakui bahwa anak-anak mengalami kesulitan untuk melakukan perpindahan sentra setiap hari dengan proyek-proyek yang berbeda sehingga akhirnya banyak anak yang mengalami project missed.

“Karena kita pernah berdiskusi lalu terpikirkan kalau misalnya anak-anak itu setiap hari berganti sentra yang pertama mereka akan lebih susah untuk mengenal, anak-anak akan bingung "kenapa kok aku sehari disini, sehari disana?" (D)

"Kita melihat sebenarnya begini, bisa dilihat kalau 1 hari 1 sentra itu ya "one day one project bisa" hanya memang tidak utuh. Kalau anak-anak itu ada 1 project yang besar yang harus diselesaikan beberapa waktu mereka keputus apalagi disini ada 5 sentra setelah sentra ini besoknya ke sentra mana lagi 'nah kadang sudah lupa. Akhirnya 
bagaimana kalau kita ubah? Toh sama-sama tentang moving tapi movingnya 1 minggu 1 kali." (K)

"Kalau 1 hari dengan pemahaman konsep anak tidak bisa lebih fokus, karena anak di hari pertama belum selesai besoknya sudah pindah di kelas lain lagi, begitu seterusnya. Anak merasa belum puas juga." (K)

Fokus anak dalam menyelesaikan tugas atau proyect pada sentra-sentra Menjadi kepuasan anak dalam artian jika anak ada project besar yang belum terselesaikan, ada waktu ada kesempatan lebih dimana anak dapat menyelesaikan project dengan maksimal. Kegiatan anak didik di sentra lebih diutamakan adalah ketekunan dan ketuntasan dalam kegiatan main, karena kegiatan sentra lebih mengutamakan proses dari pada hasil (Dewi et al., 2017; Hanafy, 2014). Menurut subyek dengan pembelajaran yang seperti ini anak lebih settel, lebih siap, dan merasa tidak bingung. Perubahan kebijakan ini sangat efektif dilakukan karena yang dulunya satu hari dengan satu sentra mereka ajarkan, kini dapat mereka ajarkan kepada secara bertahap selama 1 minggu itu. Jadi, apa yang mereka ajarkan itu dapat 'mengena' kepada anak.

"Menurut kami, ada beberapa kegiatan yang harus terpatok dengan waktu jadi harus 1 hari selesai. Dengan harapan yang baru ini, anak-anak semakin lebih mengenal, dan kegiatan pembelajaran yang kami berikan juga bisa maksimal kepada anak.Dan dengan kebijakan yang baru ini, kita harus lebih kreatif dan bervariasi untuk memberikan kegiatan yang akan kita berikan kepada anak supaya anak itu selalu eksaitet untuk tinggal selama 1 minggu di masing-masing sentra." (D)

"Karena, anak-anak lebih memahami dan lebih mengena tentang pelajaran yang diberikan di tiap sentra. Jadi, misalnya dengan kebijakan yang lalu dengan setiap harinya berpindah ke sentra yang berbeda, ketika di hari tersebut ada karya yang belum terselesaikan akan di pending dan bisa di lanjut untuk minggu berikutnya.Tetapi, untuk kebijakan yang sekarang ini kami bisa memberikan kesempatan untuk anak-anak ketika ada project di hari tersebut dan belum terselesaikan bisa di lanjut di hari besoknya. Dan dengan ini, anakanak akan lebih paham dengan step by step dalam pembuatan project tersebut." (W)

"Karena, pertama mungkin anak-anak dengan 1 minggu kelasnya full di sentra-sentra itu saja, mungkin menjadikan anak akan lebih fokus. Dalam artian, misal satu hari itu bermain membuat kriya belum selesai, nah nanti bisa dilanjutkan di esok hari. Untuk kebijakan yang sebelumnya 1 minggu dengan setiap harinya berpindah di sentra-sentra akan membuat anak tidak akan fokus di dalam mengikuti pembelajaran, dalam artian jika ada kegiatan yang belum terselesaikan di hari tersebut sedangkan esoknya anak akan berpindah di kelas sentra lain lagi akan membuat anak merasa bingung. Yang tadinya anak akan bisa melanjutkan kegiatan bermain hari kemarin tetapi dengan hari besoknya anak akan berpindah di sentra lain." (Y1)

Kesulitan guru membuat rancangan pembelajaran. Para guru ingin lebih mengakomodasi permintaan dan minat anak. Sehingga setiap harinya mereka dapat menanyakan apa yang anak-anak inginkan. Sehingga dengan demikian tidak ada kesan menuntut, akan tetapi memberi kebebasan anak untuk bermain, untuk melakukan segala sesuatu yang sesuai dengan keinginannya (Ahmad Susanto, 2011; Rohmah, 2016). Dengan demikian, hal ini diharapkan dapat mempermudah guru untuk merancang pembelajaran yang sesuai dengan minat dan kemampuan anak serta ketercapaian tujuan pembelajaran menjadi lebih maksimal.

"Di beberapa hal juga itu mempermudah guru dalam administrasi pembuatan RPPM, RPPHnya. Terus apalagi sekarang juga kalau berpusat pada anak kan bukan guru lagi menyediakan ide tapi anak yang menyediakan ide. Jadinya kalau 1 minggu itu kelihatan banget ide anak itu mau apa." (K) 
“...kita bisa terus membuat target-target anak di setiap hari supaya mereka terus terikat dengan permainan yang mereka bangun hari ini. Jadi, kita membuat anak-anak lebih maksimal di setiap permainan yang mereka lakukan." (Y2)

Kesulitan guru melakukan evaluasi. Perubahan kebijakan satu sentra per minggu juga didasarkan pada kesulitan guru untuk lebih mengetahui atau mendalami sejauh mana perkembangan anak tersebut, apa yang belum bisa anak dicapai, apa yang harus mereka lakukan agar tercapai dan apa yang harus di stimulasi kepada anak. Keterbatasan guru dalam mengamati setiap perkembangan anak juga menjadi alasan penting mengapa perubahan kebijakan ini diperlukan.

"Dengan adanya kebijakan yang baru ini, menurut saya lebih enak karena kita akan lebih mudah untuk mengamati anak. Lebih bisa fokus ke perkembangan anak, misal di dalam 1 minggu nanti saya akan mengajar kelas apa. Di dalam kegiatan hari pertama anak belum bisa melakukan hal ini, eh ternyata besoknya anak sudah bisa melakukan, dan hari berikutnya anak akan lebih bisa melakukan sesuatu dengan baik lagi. Kalau dengan pembelajaran yang dulunya 1 minggu dengan 5 sentra yang berbeda-beda menurut saya menjadi suatu kendala dalam mengamati perkembangan pada anak." (P)

"...kita perlu waktu yang lebih banyak untuk mengetahui perkembangan anak di salah satu sentra itulah sebabnya kita berfikir bahwa seminggu sekali dalam 1 sentra adalah hal yang paling mungkin dimana anak-anak bisa mengembangkan kemampuan mereka secara lebih komprehensif kemudian anak bisa melanjutkan permainannya di esok harinya." (Y2) "... selama 1 minggu itu anak-anak diberi project apa, supaya tujuannya bisa detail dalam memahami tumbuh kembang pada anak."(L)

\section{Kelebihan dan Kekurangan dari Penerapan Pendekatan BCCT}

Kekurangan antara lain: a) pembagian waktu pendidik dalam membuat $\mathrm{RKH}$; b) pendidik dirasa masih kurang dalam mengembangkan ragam main dan menciptakan APE yang disesuaikan dengan tema; c) pola perubahan (jika ada perubahan kebijakan di sekolah); d) SDM.

"Yang kebanyakan menghambat ya SDM. Pola-pola lama perubahan itu ya namanya manusia ya butuh waktu untuk berubah jadi setiap kali ada perubahan kita mulai dari nol lagi, saya harus bimbing dari awal lagi dan itu kadang yang membuat kita harus belajar cepat." (K)

"Kami sedang berusaha untuk beradaptasi dengan sistem yang baru ini, kami mencari berbagai cara atau solusi ketika anak-anak merasa bosan dengan kegiatan yang ada di kelas.(D)

"Untuk kendala di kelas pasti akan selalu ada kendala yang dihadapi, misal di pagi hari ketika masuk di kelas kadang mood anak belum stabil, kadang-kadang mereka masih butuh waktu untuk mereka bisa bergabung di kelas." (Y2)

"Kendala pasti ada karena kami tidak ada masa transisi, dari yang 1 hari 1 sentra kemudian kami berubah menjadi 1 minggu 1 sentra."(W)

Kelebihan dalam penerapan pendekatan BCCTyang dilakukan dengan perubahan kebijakan baru antara lain: a) hubungan interaksi yang terjalin antara pendidik dengan orang tua sangat baik; b) fasilitas atau sarana prasarana yang ada sudah cukup memadai; c) kurikulum sudah terstruktur untuk membantu pendidik dalam membuat RKM dan RKH; dan d) minimnya kebosanan anak.

"Sebenarnya dari sarpas atau apa itu faktor yang gampang sekali jadi misalnya kebetulan di sekolah ini banyak ruangan, jadi untuk ruangan aman.... Faktor pendukung disini banyak sekali tidak hanya ruangan saja tapi juga pohon-pohon kita maish punya, dimana di sekolah lain udah gak ada pohon semua di paving. Kita masih kaya dengan sensori yang bisa menstimulasi anak." (K) 
“...kendala-kendala kecil dan itupun masih bisa kami atasi berdua. Jadi kita kerjasama untuk mengatasi...." (P)

Dengan adanya perubahan kebijakan, subyek mengatakan bahwa tidak ada suatu kendala/masalah terkaitkebosanan anak dalam mengikuti pembelajaran di kelas. Anak-anak justru merasa senang dan kaya akan ide yang didapatkan. Kegiatan di kelas setiap harinya berbeda-beda karena kegiatan yang guru siapkan di kelas sesuai permintaan anak itu sendiri dan sesuai ide yang dimilikinya (Putro, 2016).

"Melihat dengan kondisi anak di kelas yang terlihat bosan "kadang-kadang iya" tetapi dengan persentase kecil sekitar $10 \%$ saja sedangkan untuk anak-anak yang lain mereka merasa enjoy. Karena disatu sisi kami memberikan kebebasan kepada anak dimana anak dapat memilih sesuai pilihan dan keinginannya sendiri. Solusi jika dengan adanya hal yang terjadi di kelas ini, kami saling sharring, tukar pendapat untuk mencari cara lain supaya anak tidak merasa bosan di dalam mengikuti pembelajaran di kelas sentra tersebut." (R)

"Di kelas masterchef dan bahan alam itu kami sudah menerapkan metode pengajarannya dengan bahan-bahan loose part jadi meskipun "ada anak yang bosan" upaya yang kami lakukan yaitu menyediakan kelas itu semenarik mungkin menggunakan bahan-bahan loose part jadi ketika kami sudah menerapkan metode tersebut anak-anak sangat antusias sekali, mereka senang sekali dalam mengikutinya." (A)

"Kalau untuk anak bosan, saya rasa itu persentasenya lebih sedikit, karena dengan system yang baru ini kami lebih mendorong anak untuk memancing agar mereka mengutarakan apa yang diinginkannya, mereka mau bermain apa, mereka mau belajar tentang apa jadi guru yang menjadi fasilitator. Jadi, anak-anak bisa menentukan apa yang mereka inginkan, apa yang mereka ingin pelajari, dan kami yang akan menyediakannya. Oleh karena itu, menurut kami anak-anak tidak akan bosan dengan kegiatan di sentra selama 1 minggu ini, karena kegiatannya pun setiap hari bisa berbeda, bisa berubah dan sangat fleksibel." (D)

"...hampir semua anak terlihat sangat antusias ketika mengikuti kegiatan di sentra seni, namun tergantung juga misalnya kegiatan yang membuat mereka bosan mereka pasti asik dengan bermain sendiri. Upaya yang saya lakukan ketika terlihat anak bosan di dalam kelas yaitu saya akan mencari permainan yang lain yang lebih menarik dan anak tidak merasa bosan." (W)

\section{Upaya untuk mengatasi problematika dalam menerapkan pendekatan BCCT}

Dalam mengatasi berbagai masalah selama penerapan pendekatan BCCT ini ada beberapa hal yang dilakukan, yakni:

Pembinaan Guru. Yang mana tenaga pendidik diarahkan untuk berperan sebagai fasilitator dalam kegiatan pembelajaran. Pembinaan guru dilakukan dengan cara sistem magang atau studi banding ke pusat studi pembelajaran BCCT yang kemudian dijadikan perbandingan dalam mengembangkan Yayasan Realfunrainbow sendiri sebagaimana perluyang harus dipastikan, bagaimana mengupayakan guru PAUD yang kompeten bagi setiap anak (Oktaria, 2013; Sujiono, 2010; Zaman et al., 2010).

"Kita ikut studi banding, karena ini sesuatu yang baru caranya gimana supaya kita paham, supaya kita dapat lihat langsung. Dan juga pelatihan/ pelatihan, atau pembinaan guru juga."(K)

Diskusi/Sharing. Diskusi/sharing bersama dilakukan antara para guru, bidang kurikulum, kepala sekolah, dan dengan elemen-elemen yang terkait. Juga dilakukan diskusi secara berkala, seminggu sekali dalam satu bulan. Diskusi/sharing juga diwadahi oleh KKG (Kelompok Kerja Guru) yang membahas program-program kedepan, serta guru sentra ini diberikan kesempatan menyampaikan keluhan serta permasalahan mengenai kegiatan pembelajaran yang ada. Selain itu, kepala sekolah juga mengupayakan untuk selalu 
mengajak berdiskusi dan sharing untuk memberikan solusi yang terbaik untuk kemajuan Yayasan Realfunrainbow ini (Mulyasa, 2014; Nurmadiah, 2016).

\section{SIMPULAN}

KB/TK Realfunrainbow Preschool Salatiga telah melaksanakan pendekatan BCCT dengan 5 sentra setiap minggunya, kemudian diubah kebijakan pelaksanaannya menjadi 1 sentra. Hal ini dikarenakan adanya kebingungan pada anak, fokus anak menyelesaikan tugas atau proyek pada sentra-sentra, kesulitan guru membuat rancangan pembelajaran dan evaluasi. Perubahan ini memiliki kelebihan yaitu hubungan yang terjalin antara pendidik dengan orang tua sangat baik, fasilitas atau sarana prasarana yang ada sudah cukup memadai, kurikulum sudah terstruktur untuk membantu pendidik dalam membuat rancangan pembelajaran, dan minimnya kebosanan anak. Berbagai kendala tetap dihadapi yaitu pembagian waktu pendidik membuat $\mathrm{RKH}$, kurangnya pengembangan ragam main dan APE, pola perubahan serta kemampuan SDM, sehingga dilakukan pembinaan guru serta diskusi/sharing untuk mengatasinya.

\section{DAFTAR PUSTAKA}

Ahmad Susanto. (2011). Perkembangan anak usia dini. Jurnal Golden Age Hamzanwadi University.

Alya, A. A. (2019). Evaluasi Pembelajaran Pada PAUD. Care.

Amini, M. (2014). Hakikat Anak Usia Dini. Perkembangan Dan Konsep Dasar Pengembangan Anak Usia Dini, 65.

Chairilsyah, D. (2012). Pembentukan Kepribadian Positif Anak Sejak Usia Dini. Educhild.

Dewi, F. Y., Rini, R., \& Sofia, A. (2017). Pendekatan Beyond Centers and Circle Time (BCCT). Jurnal Pendidikan Anak.

Fauziddin, M., \& Mufarizuddin, M. (2018). Useful of Clap Hand Games for Optimalize Cogtivite Aspects in Early Childhood Education. Jurnal Obsesi : Jurnal Pendidikan Anak Usia Dini, 2(2), 162. https://doi.org/10.31004/obsesi.v2i2.76

Fitri, A. (2017). Perencanaan Pembelajaran Kurikulum 2013 Pendidikan Anak Usia Dini. Jurnal Ilmiah POTENSIA, 2(1), 1-13. https:// doi.org/10.33369/jip.2.1

Hanafy, M. S. (2014). Konsep Belajar Dan Pembelajaran. Lentera Pendidikan : Jurnal Ilmu Tarbiyah Dan Keguruan. https://doi.org/10.24252/lp.2014v17n1a5

Hasanah, U. (2019). Strategi Pembelajaran Aktif untuk Anak Usia Dini. INSANIA : Jurnal Pemikiran Alternatif Kependidikan, 23(2), 204-222. https://doi.org/10.24090/insania.v23i2.2291

Hijriati. (2017). Pengembangan Model Pembelalajaran Pendidikan Anak Usia Dini. Januari Juni.

Holis, A. (2016). Belajar Melalui Bermain untuk Pengembangan Kreativitas dan Kognitif Anak Usia Dini. Jurnal Pendidikan Universitas Garut.

Iswantiningtyas, V., \& Wulansari, W. (2019). Penanaman Pendidikan Karakter pada Model Pembelajaran BCCT (Beyond Centers and Circle Time). Jurnal Obsesi : Jurnal Pendidikan Anak Usia Dini, 3(1), 110. https://doi.org/10.31004/obsesi.v3i1.106

Ma'rifah A, U., \& Muthmainnah, A. (2015). Metode Pembelajaran Bcct Dalam Mengembangkan Nilai Moral Pendidikan Karakter Anak Usia Dini. PG-PAUD Trunojoyo, 2(2), 117-124.

Moleong, L. J. (2017). Metodologi Penelitian Kualitatif (Edisi Revisi). In PT. Remaja Rosda Karya.

Mulyasa, E. (2014). Manajemen Paud. In Manajemen PAUD.

Musfiroh, T. (2012). Teori dan Konsep Bermain. Musfiroh, T., E Hum, M. (2014). Teori Dan Konsep Bermain.

Nurmadiah, N. (2016). Strategi Pembelajaran Anak Usia Dini. Al-Afkar : Jurnal Keislaman $\mathcal{E}$ Peradaban, 3(1), 1-28. https:// doi.org/10.28944/afkar.v3i1.101 
Oktaria, R. (2013). Implementasi Pendekatan Pembelajaran dalam Pendidikan Anak Usia Dini. NIZHAM.

Putro, K. Z. (2016). Mengembangkan Kreativitas Anak Melalui Bermain. Aplikasia: Jurnal Aplikasi Ilmu-Ilmu Agama. https:/ / doi.org/10.14421/aplikasia.v16i1.1170

Rahmat, P. S. (2009). Penelitian Kualitatif. In Journal Equilibrium.

Rindaningsih, I. (2012). Pengembangan Model Manajemen Strategik Berbasis (beyond center and circle Time) BCCT Pada PAUD. PEDAGOGIA: Jurnal Pendidikan, 1(2), 213. https:// doi.org/10.21070/pedagogia.v1i2.42

Rohmah, N. (2016). Bermain dan Pemanfaatannya Dalam Perkembangan Anak Usia Dini. Jurnal Tarbawi, Volume 13(2), 27-35. https:/ / doi.org/10.34001/TARBAWI.V13I2.590

Rozalena, R., \& Kristiawan, M. (2017). Pengelolaan Pembelajaran Paud Dalam Mengembangkan Potensi Anak Usia Dini. JMKSP (Jurnal Manajemen, Kepemimpinan, Dan Supervisi Pendidikan), 2(1). https://doi.org/10.31851/jmksp.v2i1.1155

Setiyarini, E., Widyasari, Y., \& Daliman, D. (2015). Pembelajaran BCCT dan Hubungannya dengan Motivasi Belajar Anak Taman Bermain. Psycho Idea, 13(2). https:/ / doi.org/10.30595/PSYCHOIDEA.V13I2.1568

Sugiyono. (2016). Memahami Penelitian Kualitatif. Bandung: Alfabeta.

Sujiono, Y. N. dan B. S. (2010). Bermain Kreatif Berbasis Kecerdasan Jamak. In Jakarta: PT Indeks.

Wiwik Pratiwi. (2017). Konsep Bermain Pada Anak Usia Dini. In Manajemen Pendidikan Islam (Vol. 5).

Yuyun Istiana. (2014). Konsep-Konsep Dasar Pendidikan Anak Usia Dini. Didaktika, Vol. 20 No. 2 Februari 2014, 5(1), 329-333. https://doi.org/10.1101/112268

Zahro, I. F. (2015). Penilaian dalam Pembelajaran Anak Usia Dini. Tunas Siliwangi.

Zaman, B., Pd, M., \& Eliyawati, H. C. (2010). Media Pembelajaran Anak Usia Dini. In Media Pembelajaran Anak Usia Dini (p. 34). http:/ / file.upi.edu/Direktori/FIP/JUR._PGTK/197010221998022-

Cucu_Eliyawati/Media_Pembelajaran_Anak_Usia_Dini-PPG_UPI.pdf 